\title{
Simulation of iron rods combustion in oxygen with the drop detachment
}

\section{S. I. Shabunja,}

\section{V. Martynenko,}

\section{I. Ignatenko}

A. V. Luikov Heat and Mass

Transfer Institute,

P. Brovka St. 15,

200072 Minsk, Belarus

E-mail:v.i.ignatenko@gmail.com
The present article is a part of the research program to study the combustion of steel in oxygen at high pressure. A fundamental understanding of iron and steel combustion in oxygen is important to the selection and specification of safe materials for oxygen production, storage and transport technologies.

In the article a standard upward-burning ignition model was considered for cylindrical iron rods in oxygen with non-flowing test conditions. A combustion model with the drops separation to investigate influence of different burning factors on the combustion process was presented. The model results were compared with the NASA experiments to clarify the values that were introduced parametrically. The present model allows to calculate and visualize such combustion parameters as burning velocities, the period of droplet detachment, temperatures and stoichiometric compositions of melt droplets, etc. The Wolfram Mathematica 9.0 program was used for simulation.

Key words: iron, metal combustion, heat conduction, burn criteria, metal flammability, melting drop formation

\section{INTRODUCTION}

The present article is a part of the research program designed to study safety of industrial production and transport of oxygen. Metal components (steel, aluminium, bronze, etc.) in the oxygen-rich environment at high pressure are also exposed to high temperatures. Under certain conditions there are processes of combustion or fast ignition that can more or less seriously damage or completely destroy the component in question. This finding is critical in terms of serviceability if this component plays an important role in the mechanical behaviour of a given structure, such as, for example, a pipeline at high pressure where the gas flows at high velocity, oxygen production or distribution plants.
Despite the fact that the problems of ignition and combustion of solid metals are being analyzed for more than half a century, most of the research was to carry out standard tests aimed to determine whether the combustion process occurs under certain conditions and finding burn criteria [1-2]. A lot of experiments were also devoted to the regression rate of the melting interface (RRMI) definition and finding the limiting mechanisms in a particular configuration of a metal rod and the environment conditions [3-8]. But it is more interesting to understand the mechanism of combustion, answer questions exactly how it proceeds and what are the parameters affecting it. Unfortunately, articles on this subject are not so numerous.

The qualitative models of iron test rod combustion in oxygen at high pressure are presented by Sato and Hirano 
[4] and Steinberg [7]. In these models, the process of metal combustion involves three main stages: 1) absorption of oxygen on the surface of the formed oxide, 2) transport of oxygen through the melt, and 3) reaction at the metal-oxide boundary. In Steinberg's papers there are an assessment of burning rate [8] and the calculation of heat transfer in the test rod [9]. The detailed work of Steinberg [10] is devoted to the modelling of rod combustion in reduced gravity. Under such conditions drops of melt are not separated from the rod.

This article presents an approach to the problem of the iron rod combustion, as well as modelling of the burning process, which allows us to understand and determine the conditions for the combustion propagation of metal in oxygen under high pressure.

\section{THEORETICAL PRINCIPLES AND MATHEMA- TICAL MODELLING. THE MODEL OF COMBUSTION. BASIC CONCEPTS}

Typical rod combustion experiments are mainly carried out in a vertical position with non-flowing test conditions [2-8]. They deal with the upward combustion, that is, the lower surface of the sample is ignited. This configuration is justified if the purpose is to create conditions for a sustainable long-term process of combustion. The drop is formed at the lower end of the rod, and it is separated from the sample under the influence of gravity, providing a better supply of oxygen to the interface reaction (Fig. 1). Just after the greater part of the molten mass drops, the remaining molten mass starts to increase again. This behaviour is repeated at regular intervals [3].

As shown by numerous experiments [11-16], the rods of different materials can be characterized by certain threshold pressure (TP) of oxygen at which steady burning of the rod begins to exist.

NASA conducted experiments with the same configuration of the rod, which is further blown by the flow of oxygen down along the rod [17-18]. These experiments showed that the rate of gas flow affects the TP of oxygen (minimum); in addition, there is a second limit - the maximum pressure at which the flame disappeared.

If there is a self-sustaining combustion process, two continuous mass flows come into the drop: $\dot{m}_{\mathrm{Fe}}(t)$ - iron flow from the rod and $\dot{m}_{\mathrm{O} 2}(t)$ - oxygen flow from the surrounding rod environment.

The component structure of the test rods affects their ability to burn for several reasons:

a) Oxidation of different metals released different amounts of energy, which affects the energy balance in the combustion region;

b) Different metals may require different amounts of oxygen for the oxidation;

c) Forming oxides of different metals have different melting and boiling points, and this can affect the properties of the melt: diffusion, viscosity, evaporation, etc.;

d) The course of different metals oxidation due to different requirements of the kinetics (different activation energies), i. e. different temperatures.

The model can be brought closer to reality by taking into account geometric factors and the specific removal of the melt. The presence of the drop, in which molten iron or steel comes through one surface (contact with the rod), and oxygen comes through another one (contact with the gaseous medium), makes it unlikely assumption of stoichiometry products. In this case, removed products contain some unoxidized alloy components; if they are oxidized later, energy from this reaction will not be transferred to the combustion region. As the drops can continue to burn in flight and on the bottom of the experimental setup, then the analysis of solidified oxides after the experiment will provide incorrect information about the composition of the drops. If the melt is mixed enough (the movies of experiments [17-18] give reason to think so), the chemical part of the model can be simplified, assuming all the functions depend only on time.

As a result, we formulate the following model:

$\checkmark$ Quasi-stationary combustion of the rod.

$\checkmark$ The energy balance is written to the melting drop.
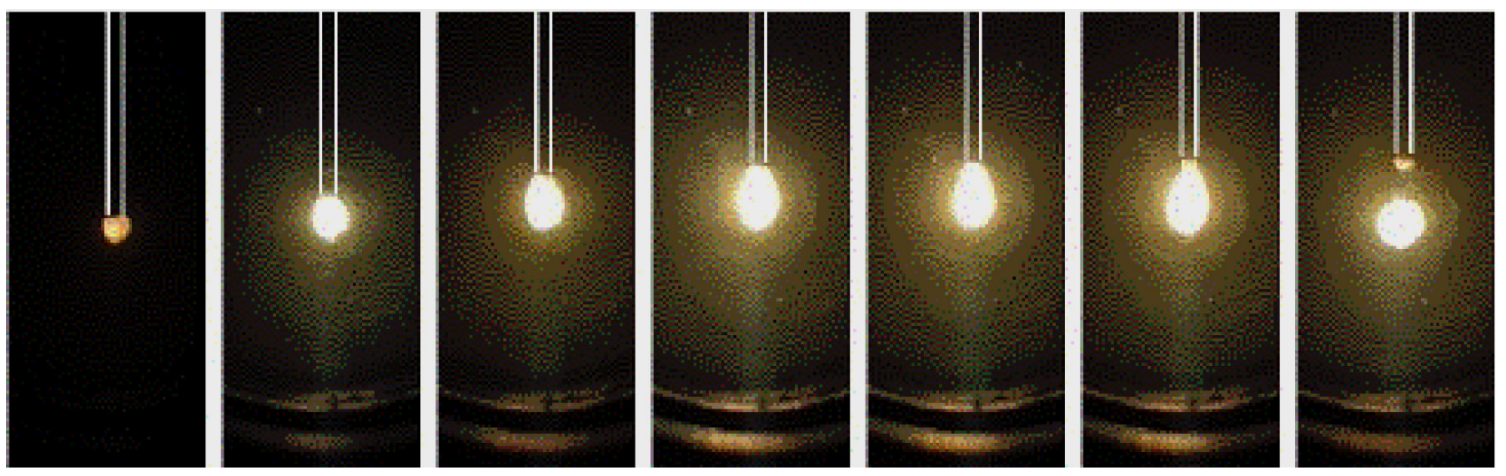

Fig. 1. Typical aspects of drop formation during the iron rod combustion 
The melting drop absorbs material of the rod and oxygen from the environment, and the melt removed from it depends on the total mass of droplet.

$\checkmark$ All the droplet characteristics depend only on time, i. e. averaged over the volume of the drop.

$\checkmark$ Chemical composition (oxygen distribution between the metal melt) is calculated by a thermodynamic equilibrium model at the average drop temperature.

\section{EXPERIMENTS}

To refine the model parameters NASA movie and test reports [17-18] were used, as well as data obtained by T. Suvorovs [19-20].

NASA reports describe the methodology and experimental setups to study the combustion of metal samples in oxygen. The experiments were conducted both in flowing and non-flowing oxygen atmosphere. Such parameters as the operating pressure of oxygen in the chamber, oxygen flow rate, sample material, its geometry were fixed. The combustion process was recorded using high-speed video.

The Suvorovs thesis presents the results of experiments on cylindrical rod combustion of various diameters from $2 \mathrm{~mm}$ to $7 \mathrm{~mm}$. There are data on the burning rate and the intensities of the separation of drops. The test reports, the experimental data and video were analyzed in order to identify the basic physical processes to create a model that can describe the evolution of the test rod burning in oxygen.

\section{MODELLING OF THE COMBUSTION PROCESS}

The physical and chemical processes that accompany the burning of cylindrical iron rods in an oxygen atmosphere at the pressure are considered. These processes include the heating and melting of iron, oxygen diffusion into molten iron, oxide formation, the radiation in the environment. Correct account of all these processes is very complicated for mathematical modelling. Therefore, it is necessary to make some simplifications. In the formulated model, the initial process of heating the metal and the initiation of combustion are not considered. Also it is believed that the energy released by the combustion of the metal is sufficient to compensate for energy losses due to radiation into the environment as well as conductive and convective heat transfer. During the iron rod combustion the drop of the oxidation products $\mathrm{FeO}$ and non-oxidized molten iron is formed. The drop substance has a certain characteristic temperature $T_{d r o p}$, which is above the iron melting point $T_{\text {melt }}$.

The amount of iron consumed in the process of drop formation is controlled by the velocity of the melting front $V_{\text {melt }}$ and is proportional to the cross-sectional area of the $\operatorname{rod} S_{\text {rod }}$. Evolution of the iron mass in the drop is as follows:

$$
\frac{d m_{F e}}{d t}=V_{m e l t} \rho_{F e} S_{r o d}
$$

where $S_{\text {rod }}=\frac{\pi d_{r o d}^{2}}{4}, \rho_{F e}$ is the density of iron.

Oxygen enters the drop across its surface bordering on gaseous environment and participates in transport processes and oxidation. The characteristic times of droplet growth clearly indicate that transport of oxygen is rather provided by convection than by molecular diffusion. To take into account the details of the oxygen transport the coefficient of oxygen transfer in the drop $V_{0}$ was introduced. It has the dimension of velocity and was determined from a comparison of experimental data and modelling results. Oxygen absorption also depends on the drop composition that is the ratio of iron to oxide; the closer it is to zero the less oxygen is absorbed. This condition is taken into account by introducing a stoichiometric ratio $\frac{m_{F e} \mu_{O}-m_{O} \mu_{F e}}{m_{F e} \mu_{O}+m_{O} \mu_{F e}}$. Summarizing all of the above, the equation describing the evolution of the adsorbed oxygen mass can be expressed as follows:

$$
\frac{d m_{O}}{d t}=\frac{m_{F e} \mu_{O}-m_{O} \mu_{F e}}{m_{F e} \mu_{O}+m_{O} \mu_{F e}} \rho_{O}^{a m b} V_{O} S_{d r o p},
$$

where $\rho_{02}^{a m b}$ is the oxygen density at the ambient temperature.

$$
S_{\text {drop }}=\beta_{\text {shape }}\left(\frac{m_{\text {drop }}}{\rho_{F e O}}\right)^{2 / 3} \text {, }
$$

where $\beta_{\text {shape }}$ is the coefficient depending on the shape of the melt droplet. As the shape of melt droplets is nearly spherical, this value can vary within a narrow range that can be considered as known within the limits of model accuracy. In the calculations, this ratio was assumed to be 3.5.

The evolution of the drop enthalpy over time is due to the following factors: the iron and oxygen flows, radiation heat that is lost to the environment $\left(T_{0}\right)$ and convective heat transfer from the drop $\left(T_{\text {drop }}\right)$ in the rod across the melt boundary $\left(T_{\text {mell }}\right)$ :

$$
\begin{aligned}
& \frac{d H_{\text {drop }}}{d t}=h_{F e}\left(T_{\text {melt }}\right) \frac{d m_{F e}}{d t}+h_{O}\left(T_{\text {melt }}\right) \frac{d m_{O}}{d t}- \\
& -S_{\text {drop }} \sigma_{\text {Boltzman }} \varepsilon\left(T_{\text {drop }}^{4}-T_{0}^{4}\right)-S_{\text {rod }} a_{h t}\left(T_{\text {drop }}-T_{\text {melt }}\right) .
\end{aligned}
$$

Recorded heat flux in the rod contains the heat transfer coefficient $a_{h t}$ which appears because of the averaging of the drop temperature. Similarly to the oxygen transfer coefficient $V_{O}$ in the drop, the heat transfer coefficient is determined from a comparison of experimental data and modelling results.

The evolution of the drop enthalpy (4) requires an additional relation connecting the enthalpy $H_{\text {drop }}$ and the temperature $T_{d r o p}$. In order to determine this relation, it is assumed the droplet consists of $\mathrm{FeO}$ and $\mathrm{Fe}$. Using known 
temperature dependences of their enthalpies $h_{F e O}(T)$ and $h_{F e}(T)$, the transcendental equation can be written as follows:

$$
H_{\text {drop }} \frac{m_{F e} \mu_{O}-m_{O} \mu_{F e}}{\mu_{O}} h_{F e}\left(T_{\text {drop }}\right)+\frac{m_{O} \mu_{F e O}}{\mu_{O}} h_{F e O}\left(T_{\text {drop }}\right) .
$$

Heat flow in the rod can be described as a dimensional quasi-stationary solution for the melting of the rod with the front velocity $V_{\text {melt }}$ :

$$
J_{\text {therm_cond }}=\lambda \frac{d T}{d x}=\rho_{F e} V_{\text {melt }}\left(h_{F e}\left(T_{\text {melt }}\right)+h_{F e}^{\text {meling }}-h_{F e}\left(T_{0}\right)\right) \text {, }
$$

which takes into account heating and phase transition.

On the other hand, heat flow is proportional to the difference between the drop and the molten iron temperatures:

$$
J_{h t}=a_{h t}\left(T_{d r o p}-T_{\text {melt }}\right) .
$$

The factor $a_{h t}$ includes all the mechanisms of convectiveconductive heat transfer between the molten drop and rod.

The flows are equal $J_{\text {therm_cond }}=J_{h t}$ it gives the value of burning velocity (the velocity of the melting front):

$$
V_{\text {melt }}=\frac{a_{h t}\left(T_{\text {drop }}-T_{\text {melt }}\right)}{\rho_{F e}\left(h_{F e}\left(T_{\text {melt }}\right)+h_{F e}^{\text {melting }}-h_{F e}\left(T_{0}\right)\right)} h .
$$

The system of the presented equations $(1-5,8)$ is completed and can be numerically integrated over time. Since all functions should be periodic, then the integration interval is from 0 up to detachment period $\tau$.

During the combustion gravity affects the drop $F_{\text {gravity }}=m_{\text {dropg }} g$ and tends to deform the shape of the interface between the liquid and the surrounding oxygen atmosphere. Gravity counteracts the surface tension

$$
F_{\text {Surffens }}=\frac{\sigma_{\text {drop }}\left(R_{\text {rod }}+R_{\text {drop }}\right)}{R_{\text {rod }} R_{\text {drop }}} S_{\text {rod }}
$$

which prevents detachment of the drop from the rod. With the growth of the drop mass its size increases, and the surface tension decreases. In the non-flowing test conditions detachment of the drop precedes the imbalance of forces of gravity and surface tension. Droplet detachment occurs some time later. Based on the experimental data [20], using the mass balance there were calculated diameters of droplets for different rod diameters. Approximating the data, the condition of drops separation was obtained:

$$
R_{\text {drop }}(\tau)=1.71+0.44 R_{\text {rod }}
$$

As noted above, the process of combustion initiation of the rod is not considered in this model. It is assumed that the rod is burning already. Moreover, steady periodic behaviour is simulated, that is, it is covered by the period between two successive drop detachments. Initial conditions are set from the periodicity of the combustion process. Temperature at the beginning of a new period is equal to the temperature at the end of the previous period. It also introduces two constant coefficients, mass loss rates and the composition of the melting drops after separation:

$$
\begin{aligned}
& T_{\text {drop } \_0}=T_{\text {drop }}(\tau), C_{M}=\frac{m_{F e_{0} 0}+m_{O_{-} 0}}{m_{F e}(\tau)+m_{O}(\tau)}, \\
& C_{F e O / F e}=\frac{m_{O_{-} 0} \mu_{F e O}}{m_{F_{-} 0} \mu_{O_{O}-} m_{O_{-} 0} \mu_{F e}} .
\end{aligned}
$$

Together with the previously introduced oxygen transfer coefficient $V_{O}$ and the coefficient of the heat transfer $a_{h t}$, they are tuning parameters.

For the given parameters the model is reduced to the solution of three ordinary differential equations $(1-2,4)$ with initial conditions (11), which are determined in the course of iterations until the condition (10) became true.

If the conditions of iteration convergence are fulfilled, the numerical solution is completed, and solution results can be compared with experimental data. During the modelling the rate of the melting front, the temperature drops, its composition and the period of separation drops are determined. By changing the values of parameters $V_{O}, a_{h t}$, $C_{M}$ and $C_{\mathrm{FeO} / \mathrm{Fe}}$ the best agreement between the calculated and experimental data can be found by minimization of the functional:

$$
\Phi=\sum_{i=1}^{6}\left(\frac{V_{\text {melt_ex }}^{i}-V_{\text {melt_calc }}^{i}}{V_{\text {melt_ex }}^{i}+V_{\text {melt_calc }}^{i}}\right)^{2}+\sum_{i=1}^{6}\left(\frac{\tau_{e x}^{i}-\tau_{\text {calc }}^{i}}{\tau_{\text {ex }}^{i}+\tau_{\text {calc }}^{i}}\right)^{2},
$$

that includes experimental data for six diameters of the test rods [20].

\section{RESULTS AND DISCUSSION}

Modelling was carried out in the Wolfram Mathematica 9.0. Simulation of rod combustion and formation of the drop is reduced to the numerical integration of differential equations $(1,2,4)$ with initial conditions (11) which are determined in the course of iterations. During the integration the program calculates the drop mass and its enthalpy. The temperature of the drop can be determined from the enthalpies. The integration is terminated at the time when the relation (10) occurs.

By minimization of the functional (12) the optimal values of tuning coefficients were determined:

$$
\begin{aligned}
& V_{O} \approx 0.12 \mathrm{~m} / \mathrm{s}, a_{h t} \approx 2.25 \cdot 10^{5} \mathrm{~W} / \mathrm{m}^{2} / \mathrm{K}, \\
& C_{M} \approx 0.08 \text { and } C_{\mathrm{FeO} / \mathrm{Fe}} \approx 0.52 .
\end{aligned}
$$

The measured and calculated values of burning velocity and periods of droplet detachment versus test rod diameters are shown on Figs. 2-3. 

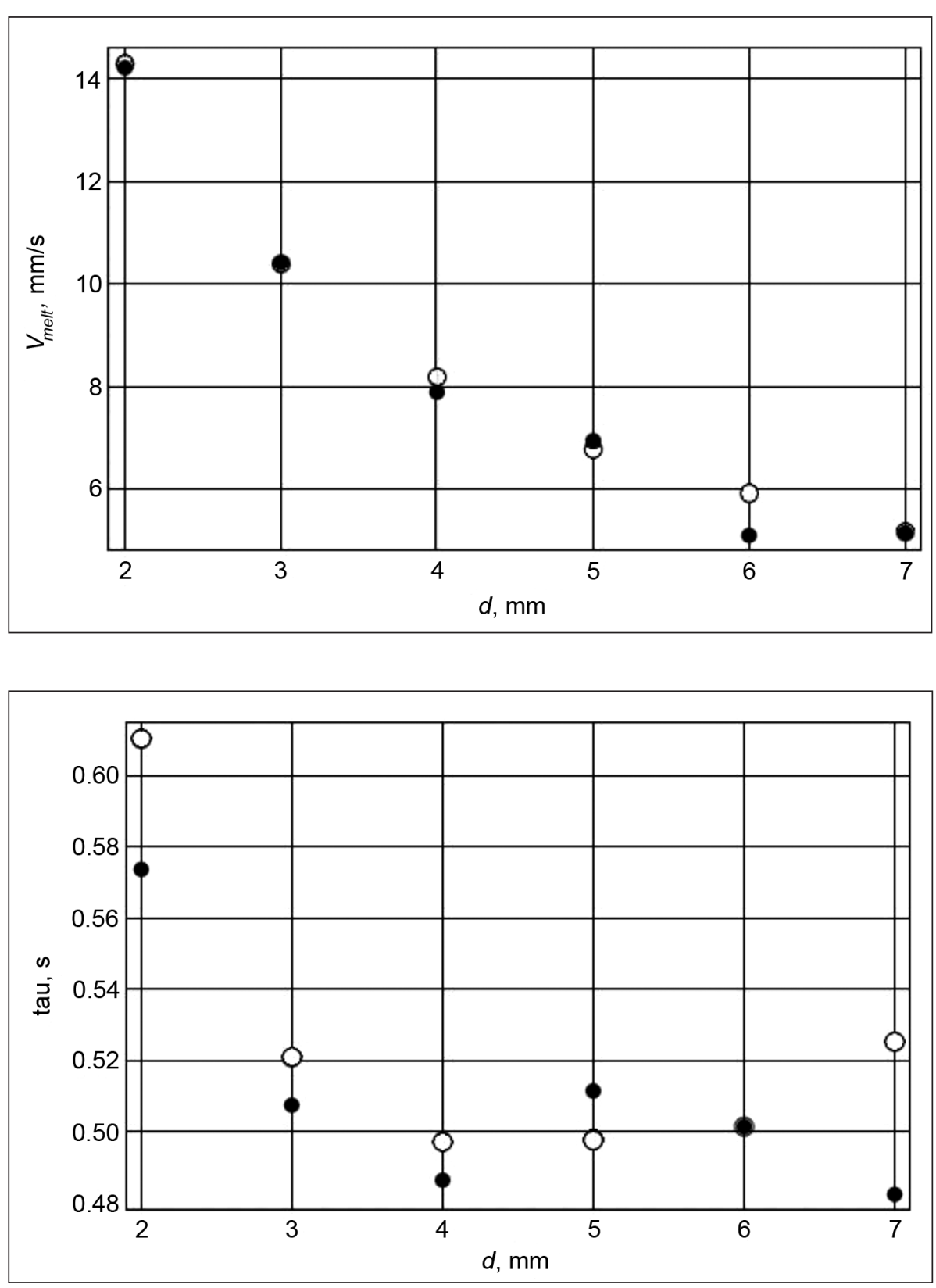

Fig. 2. Calculated (o) and experimental $(\bullet)$ values of the burning velocity $V_{\text {melt }}$ versus the test rod diameter
Fig. 3. Calculated (o) and experimental $(\bullet)$ values of the droplet detachment $\mathrm{T}$ versus the test rod diameter
Both calculated and experimental burning velocities (Fig. 2) demonstrate a monotonic decrease with an increasing diameter of the rod. It can be explained by a decrease in the proportion of oxidized iron in the droplet and an increase in the proportion of thermal losses. At the same time it is clear that the burning velocity cannot be decreased down to zero. In case of any mechanism controlling removal of the formed melt from the burning surface (gravity and / or blowing), there is some minimum value of burning velocity. Further reduction in the intensity of the process will result rather in combustion extinction than in decrease of burning velocity.

The period of droplet detachment (Fig. 3) is not a monotonic function. The results of numerical simulation have an explicit minimum at the diameter $d_{\text {rod }}=4 \mathrm{~mm}$, while the experimental data demonstrate an irregular behaviour to the right of this point. The regular behaviour of calculation results is likely to be the result of applying (10). In fact, the right side of the point $4 \mathrm{~mm}$ diameter approaches the critical extinction diameter of the rod.

Figures 4 and 5 show the results of simulations to predict the parameters of combustion, for which we have no experimental analogues. The droplet temperature (Fig. 4) monotonically decreases with diameter, which is consistent with the behaviour of velocity. However, the calculated values of the temperature are lower by a thousand degrees than the adiabatic estimate for the complete oxidation. The stoichiometric composition of melt droplets (Fig. 5), i. e. the ratio of oxygen (oxide) and the total iron molecules in the drop, explains why such a result is obtained seeing we are dealing with a non-oxidized melt. Also it should be noted that the calculation gives the average temperature of the 
Fig. 4. Temperature of the melt droplets $T_{\text {drop }}\left(d_{\text {rod }}\right)$
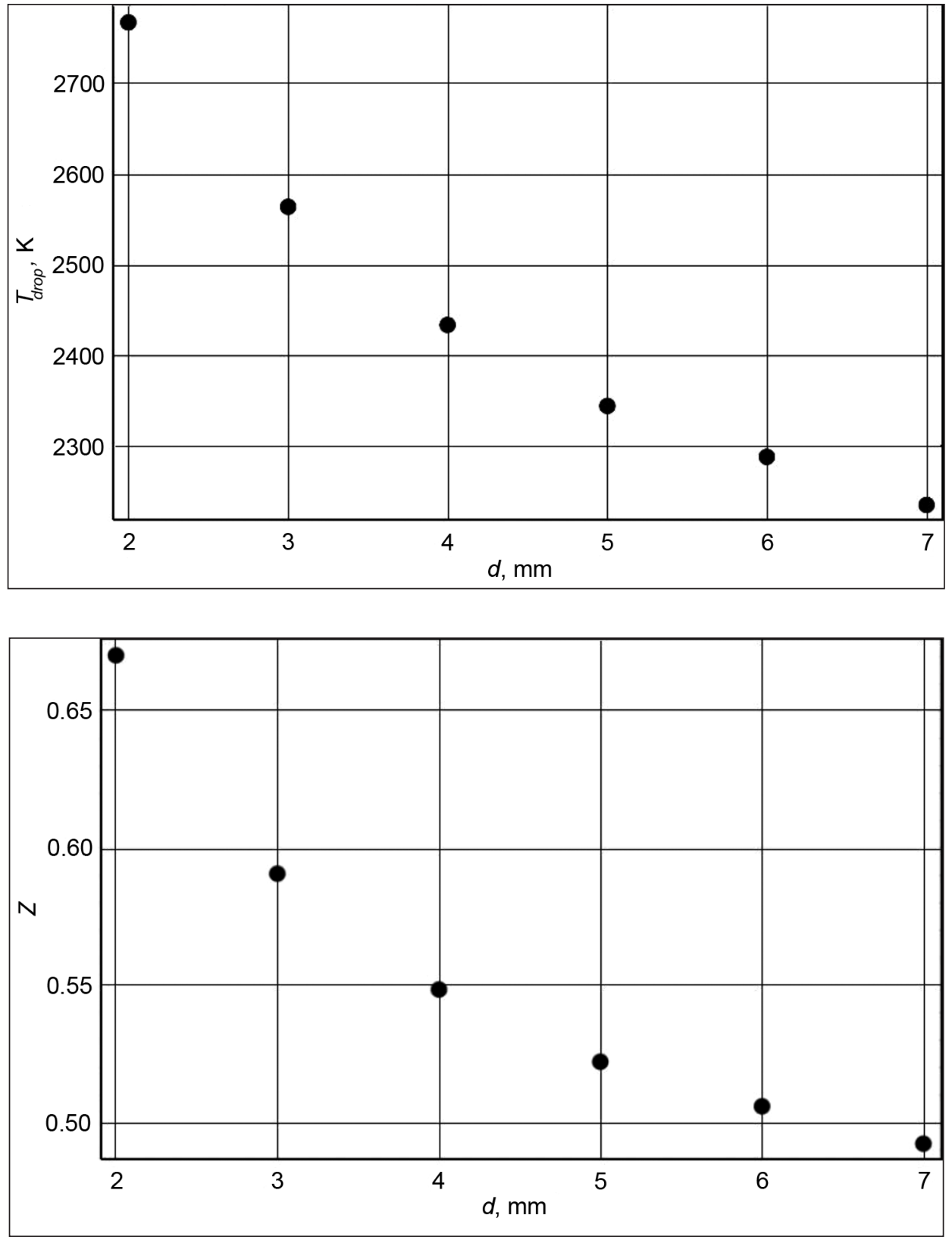

Fig. 5. The stoichiometric composition of melt droplets $Z_{\text {drop }}\left(d_{\text {rod }}\right)$ number of complex physical processes, it is unlikely to expect that they can be accurately restored only by kinematics. To improve the model, it is desirable to add the experimental information on temperature and / or droplet composition in the formulation of the functional (12). Another variant is the successive replacement of $V_{0}, a_{h t}, C_{M}$ and $C_{\text {Feo/Fe }}$ parameters by a more detailed description of the relevant physical processes. Detailed models of oxygen transport and heat transfer inside the melt droplet should lead to the replacement of the integral parameters $V_{o}$ and $a_{h t}$ by more specific characteristics of the formed melt and gas medium. The transient model of droplet growth from the loss of its stability up to detachment would specify the parameter $C_{M}$ and dependence (10). Probably $C_{\mathrm{FeOFe}}$ has little effect on the modelling result and can be replaced by the corresponding value of the droplet composition determined at detachment. composition. Since model parameters are responsible for a 


\section{CONCLUSIONS}

This article presents a model developed to simulate burning of test rods with an upward spread of fire in oxygen atmosphere with non-flowing test conditions. It contains the basic concepts and findings. Simulation was carried out in the Wolfram Mathematica 9.0.

Potentially it contains the possibility of including a variety of factors that affect burning velocity, such as the diameter of the test rod, the pressure of oxygen, the velocity of oxygen blowing, the initial heating of the test rod and the metal alloy composition. The principal limitation of the developed model is that merely periodic solutions are determined, i. e. the model cannot predict whether obtained solutions are stable or not. The model is developed to predict combustion of vertical rods ignited at the bottom. Modification of the model to simulate combustion of inclined rods by an angle up to $90^{\circ}$ seems quite realizable. Modelling of test rods burning down requires taking into account the interaction of formed melt with the test rod, which needs fundamental changes in the formulation of the model.

The developed model is tuned by experimental data [20] obtained under a pressure of $7 \mathrm{MPa}$, which simplified the initial tuning. Naturally, the model describes well this set of data. To improve the modelling of oxygen adsorption the pressure dependence of the parameter $V_{0}$ is necessary.

Determined values $V_{O} \approx 0.12 \mathrm{~m} / \mathrm{s}, a_{h t} \approx 2.25 \cdot 10^{5} \mathrm{~W} /$ $\mathrm{m}^{2} / \mathrm{K}, C_{M} \approx 0.08$ and $C_{\mathrm{FeO} / \mathrm{Fe}} \approx 0.52$ raise certain interest because they can be used as a reference for combustion models of a similar type developed for other geometries, e. g. holes and plates.

Received 20 June 2013 Accepted 30 August 2013

\section{References}

1. Deann L. E., Thomson W. R. Ignition characteristics of metals and alloys. ARS Journal. 1961. Vol. 31. No. 7. P. 917-923.

2. Slockers M. J., Robles-Culbreth R. Ignition of metals at high-temperatures in oxygen. Flammability and Sensitivity of Materials in Oxygen-Enriched Atmospheres. 2006. Vol. 11. P. 62-79.

3. Sato J., Hirano T. Fire spread mechanisms along steel cylinders in high pressure oxygen. Combustion and Flame. 1983. Vol. 51. P. 279-287.

4. Sato J., Hirano T. Fire spread rates along steal cylinders in high pressure oxygen. Flammability and Sensitivity of Materials in Oxygen-Enriched Atmospheres. 1989. Vol. 4. P. 162-177.
5. Steinberg T. A. et al. Multiphase oxidation of metals. Metallurgical and Materials Transactions. 1997. Vol. 28. P. 1-6.

6. Steinberg T. A. et al. The combustion of iron in highpressure oxygen. Combustion and Flame. 1992. Vol. 89. P. 221-228.

7. Wilson D. B., Steinberg T. A. Thermodynamics and kinetics of burning iron. Flammability and Sensitivity of Materials in Oxygen-Enriched Atmospheres. 1997. Vol. 8. P. 240-257.

8. Ward N. R., Steinberg T. A. The rate-limiting mechanisms for the heterogeneous burning of cylindrical iron rods. Journal of ASTM International. 2009. Vol. 6.

9. Lynn D. B., Steinberg T. A., Sparks K., Stoltzfus J. M. Defining the flammability of cylindrical metal rods through characterization of the thermal effects of the ignition promoter. Flammability and Sensitivity of Materials in Oxygen-Enriched Atmospheres. 2010. Vol. 12. P. 21-37.

10. Steinberg T. A., Wilson D. B., Stoltzfus J. M. Modeling the NASA/ASTM flammability test for metallic material burning in reduced gravity. Flammability and Sensitivity of Materials in Oxygen-Enriched Atmospheres. 2000. Vol. 9. P. 266-291.

11. Steinberg T. A., Rucker M. A., Beeson H. D. Promoted combustion of nine structural metals in high pressure gaseous oxygen. Flammability and Sensitivity of Materials in Oxygen-Enriched Atmospheres. 1989. Vol. 4. P. 54-75.

12. De Wit J. R., Steinberg T. A., Haas J. P. ASTM G-124 Test data for selected Al-Si alloys, Al-composites, binary alloys and stainless steels. Flammability and Sensitivity of Materials in Oxygen-Enriched Atmospheres. 2000. Vol. 9. P. 179-189.

13. Sipcas S., Stoltzfus J., Bryan C., Kazaroff J. Promoted combustion of pure metals in oxygen-enriched atmospheres. Flammability and Sensitivity of Materials in Oxygen-Enriched Atmospheres. 1995. Vol. 7. P. 100-106.

14. Werley B. L., Hansel J. G. Flammability limits of Stainless Steel Alloys 304, 308 and 316. Flammability and Sensitivity of Materials in Oxygen-Enriched Atmospheres. 1997. Vol. 8. P. 203-224.

15. Mc Ilroy K., Rucker M., Zawierucha R. The effects of testing methodology on the promoted ignitioncombustion behavior of carbon steel and 316L stainless steel in oxygen gas mixtures. Flammability and Sensitivity of Materials in Oxygen-Enriched Atmospheres. 1989. Vol. 4. P. 38-53.

16. Samant A. V., Zawierucha R., Million J. F. Thickness effects on the promoted ignition-combustion behavior of engineering alloys. Flammability and Sensitivity of Materials in Oxygen-Enriched Atmospheres. 2003. Vol. 10. P. 177-191. 
17. NASA White Sands Test Facility. Promoted Ignition in Flowing Oxygen. Special Tests Data Report. WHA Test Reports. December 2, 2004.

18. Industry-Sponsored Metals Test Program 05-1. Promoted Combustion of Metals in Flowing and Nonflowing Oxygen Environments. WHA Test Reports. April 13, 2007.

19. Suvorovs T. et al. Effects of sample geometry on regression rate of the melting interface for carbon steel burned in oxygen. Journal of ASTM International. 2006. Vol. 3(4).

20. Suvorovs T. Promoted Ignition Testing: An Investigation of Sample Geometry and Data Analysis Techniques. PhD Thesis. Queensland University of Technology, 2007.

\section{S. I. Šabunja, V. V. Martinenko, V. I. Ignatenko}

\section{GELEŽIES STRYPŲ DEGIMO DEGUONIES} APLINKOJE SU LAŠŲ ATITRŪKIMU MODELIAVIMAS

\section{Santrauka}

Straipsnyje pateikti rezultatai yra plieno degimo deguonyje esant aukštam slègiui tyrimų programos dalis. Fundamentalus geležies ir plieno degimo deguonyje dèsnių bei procesų supratimas yra svarbus klasifikuojant, atrenkant saugias medžiagas ir jų bandinius deguonies gamybos, saugojimo, transportavimo technologijas.

Straipsnyje analizuojamas standartinis cilindrinių geležies strypų, uždegtų deguonies aplinkoje iš apačios nenaudojant priverstinio apipūtimo, modelis. Pateiktasis degimo modelis su lašų atitrūkimu skirtas išaiškinti įvairių veiksnių įtaką degimo procesui. Gautieji modelio tyrimo rezultatai buvo palyginti su NASA eksperimentu duomenimis siekiant patobulinti modeli. Dabartinis modelis leidžia nustatyti ir vizualizuoti degimo parametrus, pvz., degimo greitị, lašelio atsiskyrimo periodą, temperatūrą, lydytų lašelių stechiometrinę sudèti ir kt. Skaičiavimams buvo panaudota The Wolfram Mathematica 9.0 programa.

Raktažodžiai: geležis, metalų degimas, šilumos perdavimas, degimo parametrai, lydymosi lašo formavimasis

\section{С. И. Шабунья, В. В. Мартиненко, В. И. Игнатенко}

\section{МОДЕЛИРОВАНИЕ ГОРЕНИЯ ЖЕЛЕЗНЫХ СТЕРЖНЕЙ В КИСЛОРОДЕ С УЧЕТОМ ОТРЫВА}

\section{КАПЕЛЬ}

Резюме

Представленная статья является частью исследовательской программы направленной на изучение горения сталей в кислороде при высоком давлении. Понимание законов горения железа и стали в кислороде важно для отбора и классификации безопасных образцов при работе с технологиями по производству, хранению и транспортировке кислорода.

В статье рассматривается стандартная модель горения цилиндрических железных стержней с поджигом снизу в кислородной среде без принудительного обдува. Представленная модель горения с учетом отрыва капель направлена на исследование влияния различных факторов на процесс горения. Результаты моделирования сравнивались с экспериментальными данными НАСА для уточнения значений, введенных в модель параметрически. Модель позволяет рассчитать и визуализировать такие параметры горения как скорость горения, период отрыва капли, температуры и стехиометрический состав капель и другие. Для моделирования использовалась среда The Wolfram Mathematica 9.0.

Ключевые слова: горение металлов, горение железа, параметры горения, образование капли расплава 